\title{
Ultrastructural and Histochemical Observations in the Rat Endometrium in the Early Normal Pregnancy
}

\author{
Kaname HAYASHI, Wenyuan LEE, Kenji MATSUOKA \\ and Hirosuke TAKEKIDA \\ Department of Obstetrics \& Gynecology, Kobe University, School of Medicine, Japan. \\ (Ghief : Professor Shimpei Tojo)
}

The ultrastructural changes of the endometrium early in the normal pregnancy were observed to clear the function of the endometrium that is preparing for the reception of the fertilized ovum.

Though the mechanism of ovum implantation is differ from species to species, it is reasonable to assume that there should be some common events in the fundamental aspects.

We wish to describe the functional meanings of these ultrastructural changes with histochemical findings of some enzymes such as ALPase, ACPase and ATPase, which are important substances related to the cell membrane permeability, secretion and absorption of the cell and the transport of cellular material.

The virgin Wistar strain rats were laparotomized under light Nembutal anesthesia and the uterine horn was excised immediately and was sliced and fixed in paraformaldehyde-glutaraldehyde. Then it was rinsed in buffer and was postfixed in 0s04 and processed for electron microscopy.

The observation was made mainly in the antimesometrial site of the endometrium on each day of early normal pregnancy from day L2 to day L5.

The histochemical preparation was made after Gomori's method for ALP and ACPase, and Wachstein-Meisel's method for ATPase.

1) On the day L2, the ALPase activity was mainly located in the luminal epithelia and the blood vessel wall.

The free surface of the luminal epithelia was covered with rather regular arrangement of microvilli and they were definitely covered with the filamentous structure.

The dilated microvilli was observed in the glandular epithelium and the stromal edema has already appeared.

2) On the day L3, the ATPase activity was increased in the luminal epithelia and the blood vessel has high activity of ALP and ATPase.

The microvilli in the luminal epithelia has the tendency to shorten and the filamentous structure was disappeared.

The remarkable increase of the apical vesicles was the prominent feature and the well developed Golgi complex and dilated granular endoplasmic reticulum were also 
observed.

The basement lamina revealed marked tortuosity.

The stromal edema has increased and the cytoplasma of the stromal cell was enlarged and has developed organella.

The glandular lumen has many fine granules.

3) On the day L4, the subepithelial stroma showed marked ALPase activity and the ATPase activity has also appeared.

The microvilli and apical vesicles has obviously decreased in the luminal epithelia and there was translocation of the lipid droplet to the supranuclear region.

The lysosome became complicated in its structure and increased in its number.

The ribosome has progressively increased prominently and the dilated granular endoplasmic reticulum was filled with moderate electro-dense substance.

The electron density of the glandular lumen was in its peak and it was occupied with that fine granules.

4) On the day L5, the enzymic activities were more increased in the anti-mesometrial stromal cells. The surface of luminal epithelia was entirely covered with irregular cytoplasmic protrusions and the supranuclear lipid droplet has increased in its number.

The electron density and the number of lysosome have increased.

The basal lamina was rather straight at this time but it was completely intact.

The stromal edema has decreased and the stromal cells were connected with desmosome.

Fibrillar material and cilium were also observed in the stromal cells.

The electron density in the glandular lumen has decreased and the some mitochondria of the glandular epithelia showed low electron density and was dilated.

Similar changes were observed in the luminal epithelia in the mesometrial site, but the stromal edema in this site was more prominent and the cytoplasma of the stromal cell was not well developed.

(See pp. 533 547) 


\title{
着床周辺期子宮内膜の形態に関する 電顕的・組織化学的観察
}

\author{
神戸大学医学部産科婦人科学教室（主任：東条伸平教授) \\ 林要・李文遠 \\ 松 岡 謙 二・武木田 博 祐
}

（昭和 47 年 8 月 2 日受付）

肧着床の機構を知る目的で, 着床周辺期ラット子宮内膜の微細構造の変化を観察し, 同時期の組織化 学的検索結果と共にその意義について考察した. 表面上皮の微細構造は $\mathrm{L}_{3}$ において著変がみられ，乙 の時期では表面上皮の分泌能の充進するてとが推測できた。しかし $\mathrm{L}_{4}$ では表面上皮の吸収能がたかま るととが予測され，また間質の浮腫，腺上皮の分泌は最高であつた，さらに腺上皮は $L_{5}$ にわいてすで に機能低下を示唆する所見が得られ，乙れにかわり間質細胞の著明な機能分化をうかがわしめる所見が みられた。

はじめに

胚着床の機構を把握するには，卵側の子宮内膜に及ぼす影響と共に，子宮内膜側にわけるその準備状態の 形態学的実態を可及的精微に追求する必要のあるてとはててで論ずるまでもない.

近年々の高分解能を駆使した電子顕微鏡的観察がての分野においても盛んに応用されるようになつたのは こうした理由によるものであり，例えばラットを実験対象とした研究として Enders ${ }^{1)} ら$ (1967), Mayer ${ }^{2)}$ ら (1967), Nilsson ${ }^{3)}$ (1970), Tachi' ${ }^{4)}$ (1970), 飯塚 ${ }^{5)}$ (1971) の報告がみられる.

しかしながら，てのように比較的多数の研究結果が報ぜられているにもかかわらず，その形態学的変化の 把握や，その機能的な解橎には従来可成り見解の相違がみられる.

他方ての種の基礎的な研究は各動物にみられる種特異性のために，ある種の動物にわける研究結果を直接 他の動物，例えばヒトの着床過程にあてはめて考学るてとは幾多の難点があるが，ての反面その基本的ない くつかの過程には重大な共通点が存在するはずである.

今回我々は，着床周辺期ラット子宮内膜の変化に焦点をおき観察を行つたので，その形態学的推移と着床 に関与するその機能的な意義についての著者らの見解をててで述べてみたい.

\section{I 実 験 方 法}

臸スメア法によつて性周期の規則正しいてとをあらかじめ確認したウイスター系処女ラット（体重150〜 $200 \mathrm{~g}$ ）を発情前期に雄と同居させ，翌朝交尾の有無を胵脂亭中の精子の有無から判定し，精子が検出され た日を妊娠第一日 $\left(\mathrm{L}_{0}\right)$ とし，以後 $\mathrm{L}_{1} \mathrm{~L}_{2} \cdots \mathrm{L}_{5}$ と命名した.

電顕用標本の作成にあたつては次の如き手順に従つた。動物をペントバルビタール麻酔し開腹した後, 直 ちに子宮を切除し組織を $\mathrm{pH} 7.4$ 亿調整した paraformaldehyde-glutaraldehyde 固定液中で浸漬しつつ 1 〜 $2 \mathrm{~mm}$ に輪切し固定した.

そして上記の固定液で 1 時間固定した後, 燐酸緩衝液にうつし, その後 $2 \%$ 四酸化オスミウムで 1 時間再 固定した。 ついでエタノール系列による脱水後, プロピレンオキサイドに 2 度通し, Luft の方法に従つて 
エポキシ樹脂包埋を行つた. さらに Toluidin blau 染色後光学顕微鏡で観察部位を決定し, Porter-Blum 型ミクロトームにより超薄切片を作成し，乙れに酢酸ウラニールと酷酸鉛による二重染色を施し，日立 HS-8 型電子顕微鏡を使用して観察した。

また電子顕微鏡的観察によつて得られた細胞内小器官の変化の持つ機能的な意義を, より詳細に把握する 目的で, 細胞膜透過性, 細胞の分泌, 吸収, 細胞間の物質移動現象に関与すると言われる ALP-ase, ATPase, ACP-ase 活性の変動を, それぞれ Gomori の azo 色素法, Wachstein-Meisel 法, Gomori の azo 色素 法を用い組織化学的に検討した ${ }^{6}$.

\section{II 実 験 成 績}

本実験においては $\mathrm{L}_{2}$ からいわゆる nidus formation と呼称される $\mathrm{L}_{5}$ までの反間膜側内膜の変化に焦 点をおき観察したが， $\mathrm{L}_{5}$ 日ラットにおいては間膜側内膜についても検討を加えた.

(1) $\mathrm{L}_{2}$ 日内膜 (Table 1 Photo 1,2 )

$\mathrm{L}_{2}$ 日では，受精卵はなお卵管内を下降しており，内膜の代謝活動は組織化学的に低く，それまでみられ た精子の侵入に由来する内膜における炎症，あるいは退行像は殆んど消失する. 内膜 ALPase は主として 上皮系や血管壁に局在しており間質細胞にはほとんど認められなかつた（Table 1).

\section{微細構造所見 :}

表面上皮 : 胞体の遊離端はほぼ規則正しく配列する巾 $0.1 \sim 0.2 \mu$, 長さ $0.5 \sim 1 \mu$ 微絨毛でおおわれ, またこの微絨毛の表面は小腸に見られるのと同様に多糖類より成るといわれる微細な樹枝状構造, すなわち antennulae microvillares がみられた.

上皮表面上には直径 $0.1 \sim 0.25 \mu$ の円形の小胞が少数認められ，また中等度の大きさを持つ円形ないしは 長円形のミトコンドリアが観察された.とのほか少数のライソゾーム系顆粒が核上部に見られた。

他方基底部においては, 比較的多数の脂質顆粒や小型ミトコンドリアが分布しており, 基底膜は著しく屈 曲していた。

間質：この時期の間質組織には光顕上浮腫はまだ認められないが，電顕上すでに浮腫傾向が明らかにみら れる. 間質細胞は細胞質にそしく，核の辺縁は不整である．細胞質には少数のミトコンドリア，ライソゾー 么系顆粒や粗面小胞体が見られる。また間質組織内にはなお中性好性白血球の遊走がみられた。

腺上皮細胞 : 子宮腺細胞の微細構造は基本的には表面上皮の夫と同一構築を示しており，腺上皮の表面に は微細な樹枝状構造を持つ微絨毛でおおわれており，また一部では微絨毛が膨大したと思われる像が認めら れた。胞体内には少数の小胞，粗面小胞体，ゴルジ体やミトコンドリアがみられるが，とくに特異的な所見 はみられなかつた，核は細胞の $1 / 2$ 以上を占め，狭い基底部には少数の脂質顆粒が分布していた。また腺に

Table 1 Changes of histochemical reaction of uterus of normal pregnant rats

\begin{tabular}{|c|c|c|c|c|c|c|c|c|c|}
\hline & \multicolumn{3}{|c|}{ ALPase } & \multicolumn{3}{|c|}{ AGPase } & \multicolumn{3}{|c|}{ ATPase } \\
\hline & ep. & st. & cap. & ep. & st. & cap. & ep. & st. & cap. \\
\hline $\mathrm{L}_{0}$ & $H$ & - & $H$ & + & + & - & - & - & $H$ \\
\hline $\mathrm{L}_{1}$ & H & - & H & + & $\div$ & - & - & $\div$ & $H$ \\
\hline $\mathrm{L}_{2}$ & + & - & $H$ & + & + & - & - & $\div$ & $H$ \\
\hline $\mathrm{L}_{3}$ & + & - & H & $H$ & + & $\div$ & $\div$ & + & 世 \\
\hline $\mathrm{L}_{4}$ & + & $\div$ & $H$ & $H$ & + & $\div$ & $\div$ & + & H \\
\hline $\mathrm{L}_{5}$ & - & $H$ & $\div$ & H & $H$ & - & $\div$ & $H$ & $\div$ \\
\hline $\mathrm{L}_{6}$ & - & H & - & H & $H$ & - & - & H & - \\
\hline $\mathrm{L}_{7}$ & - & H & - & H & $H$ & - & - & H & - \\
\hline
\end{tabular}


Fig. 1. Luminal epithelium on Day $\mathrm{L}_{2}$ $\times 15,000$

Rather regular arrangement of microvilli was observed with filamentous structure.

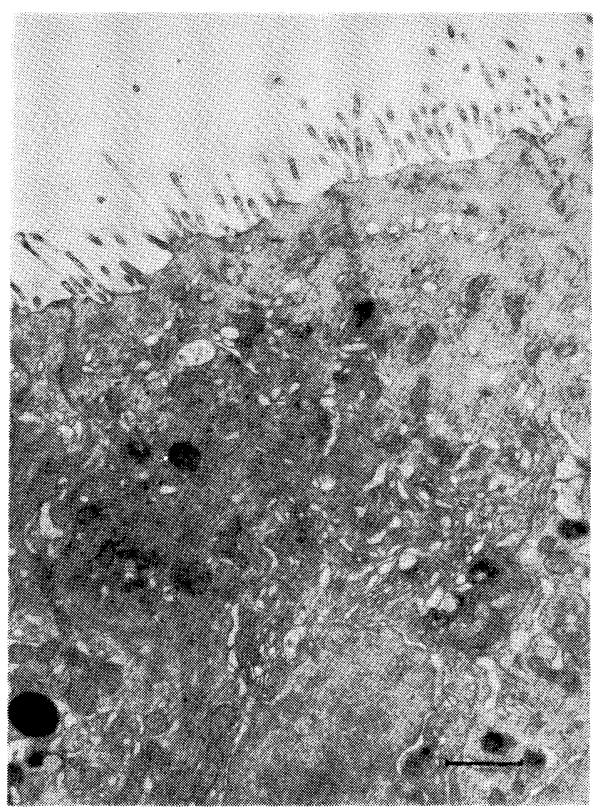

Fig. 2. Glandular epithelium on Day $\mathrm{L}_{2}$ $\times 6,000$

Dilated microvilli (arrow) was present.

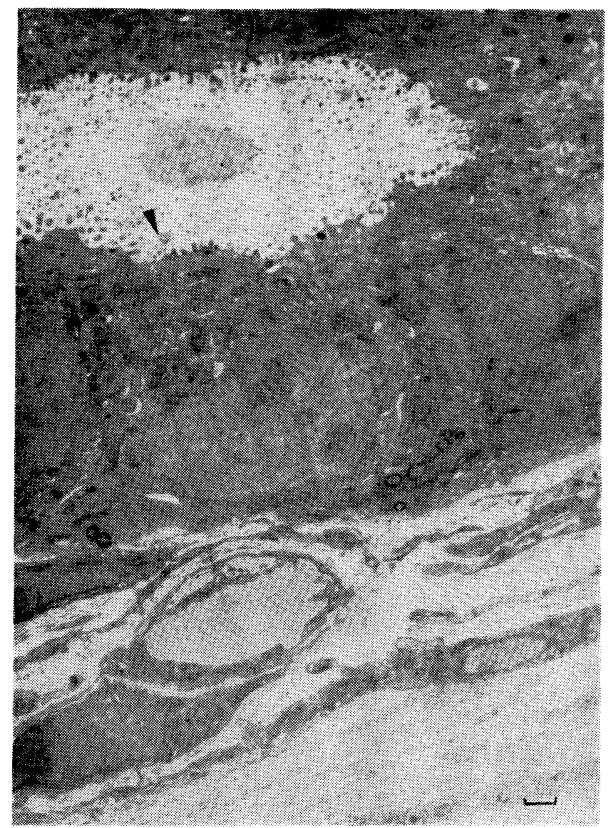

近接する毛練血管の管腔は中等度の電子密度を有する均一な物質によつて満たされており，腺附近の間質細 胞のあるものは，すでに軽度の粗面小胞体の抾大像もみられた。

(2) $\mathrm{L}_{3}$ 日内膜 (Photo $3,4,5,6,7$ )

Fig. 3. Luminal epithelium on Day $\mathrm{L}_{3} \times 24,000$ Microvilli became shortened and the filamentous structure was disappeared. Many apical vesicles were observed.

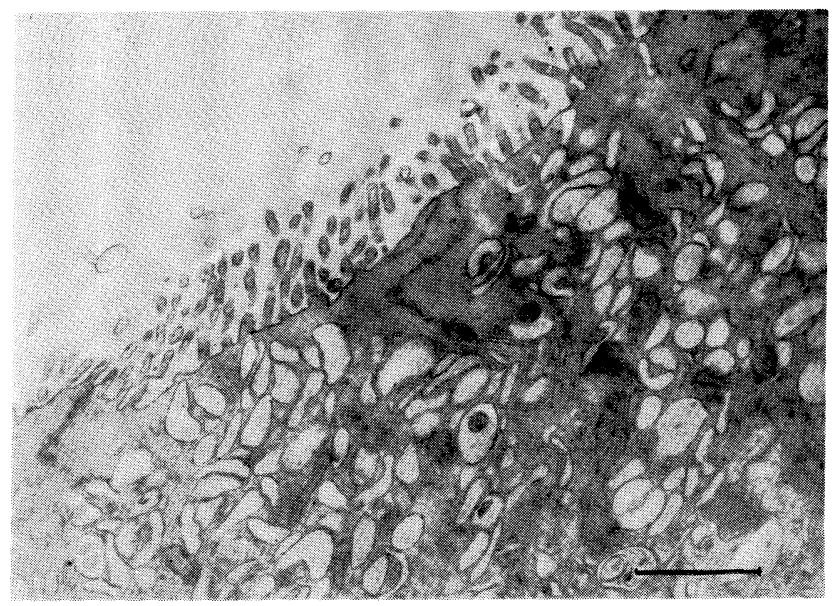

第 48 巻 第 7 号 
Fig. 5. Luminal epithelium and stromal cell

on Day $\mathrm{L}_{3} \times 11,000$

Group of mitochondria was located in the basal region and the basement lamina (arrow) showed marked tortuosity. Stromal cell had enlarged cytoplasma with dilated granular endoplasmic reticulum.

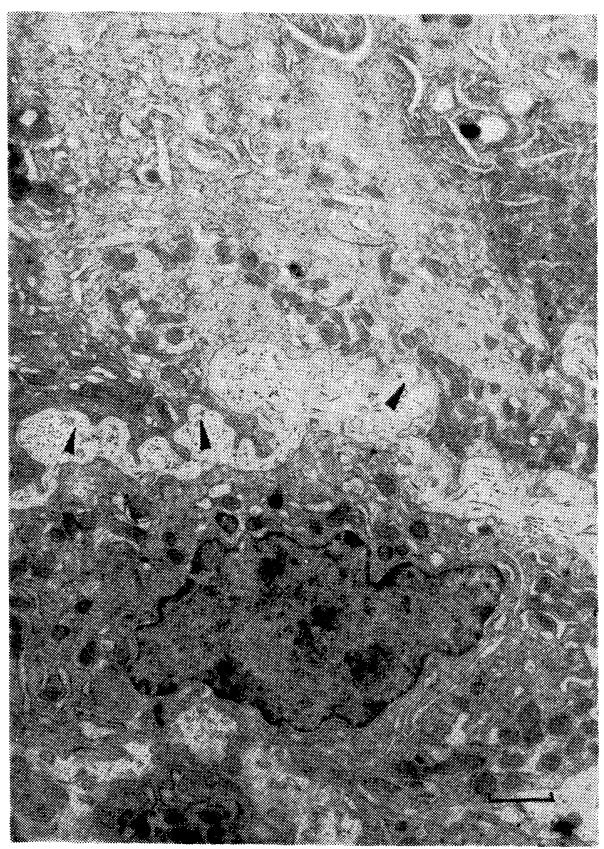

Fig. 4. Luminal epithelium on Day $\mathrm{L}_{3}$ $\times 24,000$

Well developed Golgi complex (arrow) was observed with dilated granular endoplasmic reticulum.

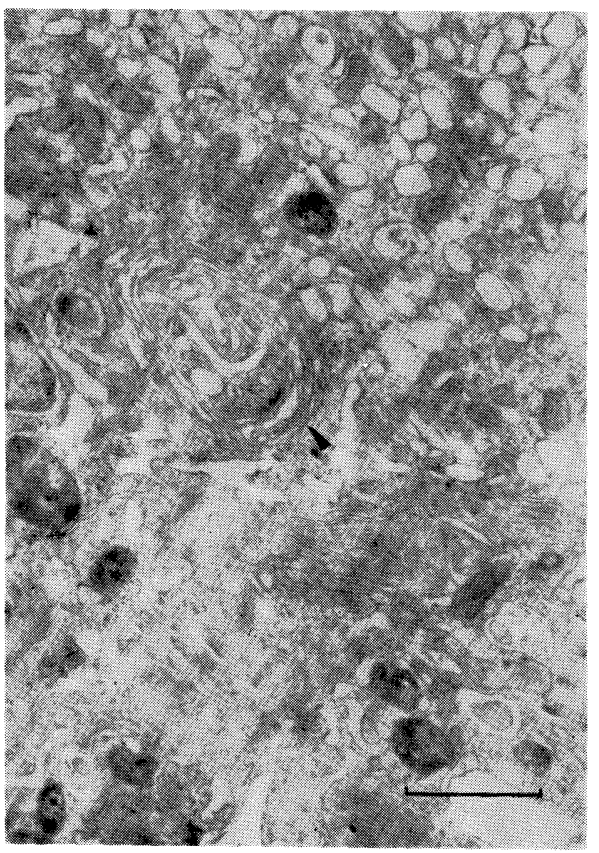

Fig. 6. Glandular epithelium on $\mathrm{Day} \mathrm{L}_{3} \times 7,500$

The nucleus occupied most part of the cytoplasma, but the mitochondria (arrow) and the lysosome has obviously increased in its number.



第 48 巻 第 7 号 
Fig. 7. Glandular epithelium on Day $\mathrm{L}_{4} \times 15,000$

The electron density in the glandular lumen has increased and the filamentous structure on the microvilli has disappeared. The fine granules were observed among the microvilli and in the lumen.

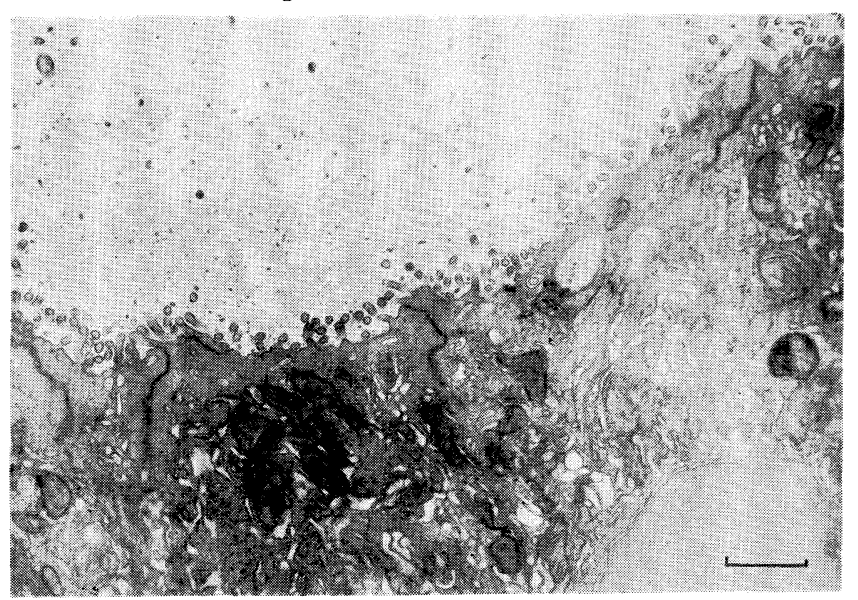

この時期においては受精卵はすでに子宮内に下降 しており，flush out 法によつて受精卵の子宮から の回収はほぼ100\%可能である。

上皮系の ALPase 活性は前日とほぼ同様な所見 を示したが，同部における ATPase 活性はやや増 加，また間質血管系の ALPase，ATPase 活性は増 強がみられた。

\section{微細構造所見}

表面上皮 : 前日と同様にほぼ規則正しく配列する 微絨毛でおおわれているが，微絾毛はやや短縮し， また前日にみられた微細な樹枝状構造は大部分消失 していた，さらに特徴的な像は，大きさ $0.1 \mu \sim 0.3 \mu$ $\times 0.1 \mu \sim 0.6 \mu$ 大の円形ないしは，長円形の大小種々 の小胞が胞体上部に多数見られることであつて，乙 の小胞内にはしばしば電子密度の高い物質が存在し ていた.

ゴルジ体は前日と比較し, その層構造の増加や拡 大がみられ，ゴルジ体の著明な発達と共に粗面小胞 体の内腔拡大像もみられた。

ミトコンドリアやライソゾーム系顆粒も前日に比 し増加傾向にあり，乙れらの微細構造の諸変化は表 面上皮の分泌機能の六進を示唆するものと推定され る.

しかし基底部のそれは, 前日に比し, 特に著変は 認められなかつた。
Fig. 8. Luminal epithelium on Day $\mathrm{L}_{4}$ (a.m.) $\times 7,500$

The arrangement of microvilli became irregular and the apical vesicles has decreased in its number. Supranuclear lipid droplets were observed.

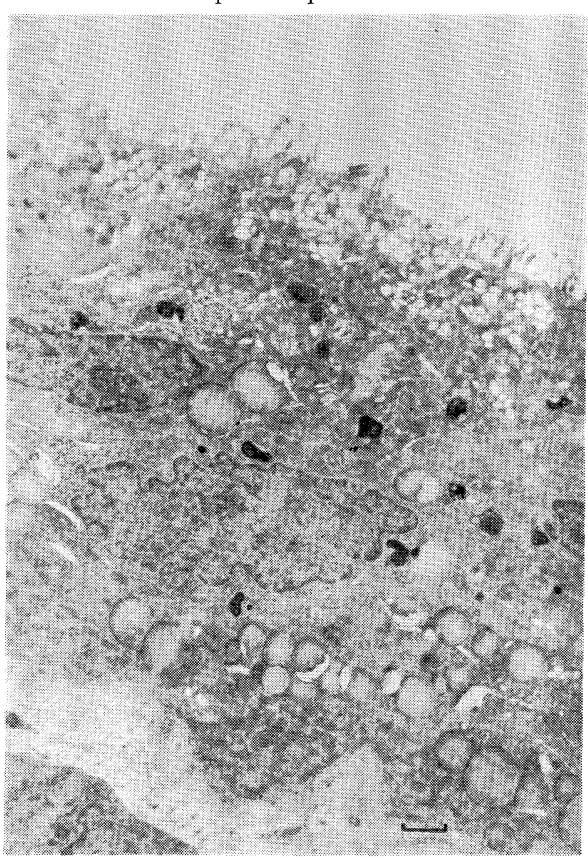


Fig. 9. Luminar epithelium on Day $\mathrm{L}_{4}$ (p.m.) $\times 15,000$ Cytoplasmic protrusion (arrow) has appeared and the apical vesicles has more decreased.

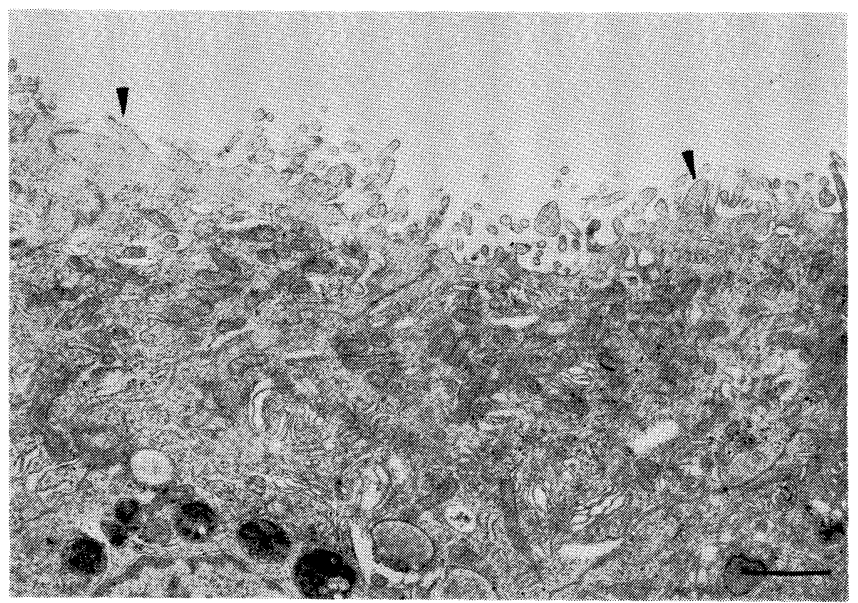

間質 : 浮腫傾向は前日よりさらにつよくなり, 間 質細胞の胞体の肥大やそれに伴う粗面小胞体の増加， さらにその内腔拡大像がみられたが，その内腔内電 子密度はそれほど高くなかつた。

腺上皮細胞：前日と同様に細胞質の大部分は核に よつて占められていたが，ミトコンドリア，ライソ ゾーム系顆粒の増加, 増大がみとめられ，またゴル ジ体においても同様な傾向が観察できた，腺腔内の 電子密度は前日より増加し，表面の微紱毛には前述 の表面上皮と同様な変化，すなわちその微細な樹枝 状構造は消失していた。 また直径 $0.1 \mu$ 前後の小顆 粒を微絨毛の間や腺腔内にみることができた。

腺細胞においてみられるこれらの諸変化は，乙の 時期における腺細胞の分泌機能の克進を思わせた.

(3) $\mathrm{L}_{4}$ 日内膜 (Photo 8, 9, 10, 11, 12)

$\mathrm{L}_{4}$ 日の午前中では胚はなお透明帯を有している が，同日の午後 4 時になると透明帯を消失し，子宮 内膜上皮間に指状㞸合 interdigitation，つまり両者 における最初の解剖学的連絡が生ずるので, この時 期を Tachi ら (1970) は early attachment stage と呼んでいる，反間膜側の間質血管系は一層増生し， その ALPase, ATPase 活性は頂点に達し, また上 皮直下の間質細胞には ACPase 活性の増加と ATPase 活性の出現がみられた (午後 4 時).
Fig. 10. Luminal epithelium on Day $\mathrm{L}_{4}$ (p.m.) $\times 15,000$ Complicated lysosomes were observed.

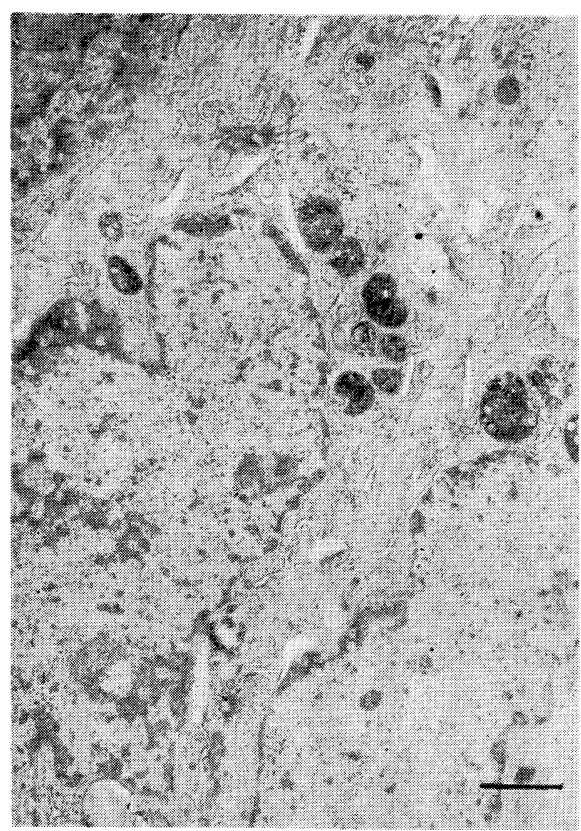

\section{微細構造所見}

表面上皮 : 午前中における表面上皮の特徵的な所見として, 微縅毛や小胞の減少傾向，さらにゴルジ体の 
Fig. 11. Stromal cell on Day $\mathrm{L}_{4}$ (p.m.) $\times 11,000$

The nucleus became rounded with moderate electrondense substance. marked stromal edema was also noted.

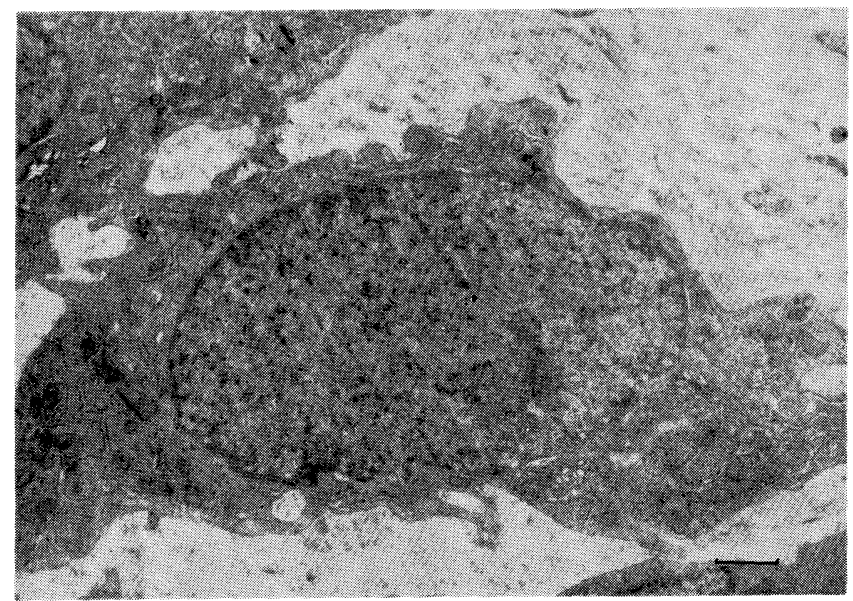

Fig. 12. Glandular epithelium on Day $\mathrm{L}_{4}$ (p.m.) $\times 7500$ The autophagosome (arrow) was observed. The fine granules in the lumen has increased and the electron density was in its peak.

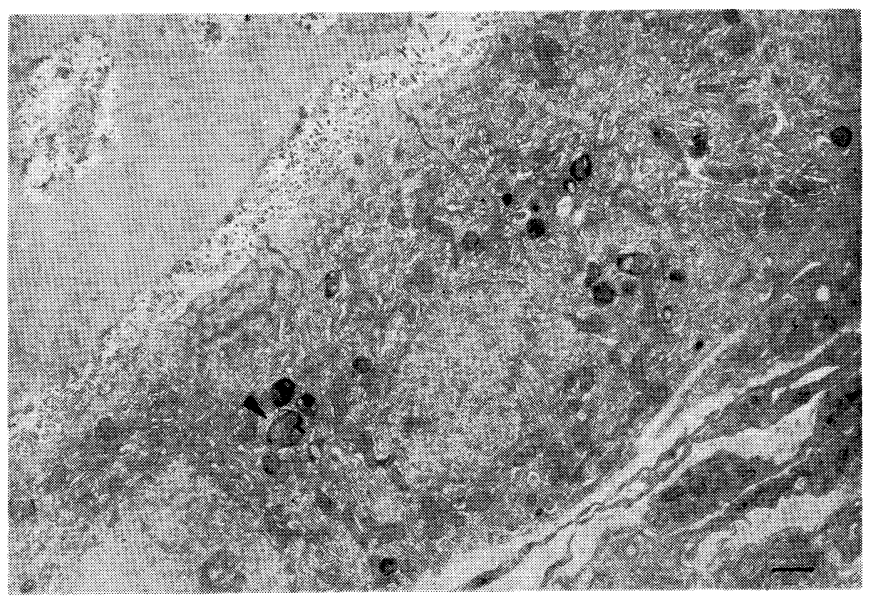

縮少傾向が見られたが，乙のほか脂質顆粓の核上部への移動が出現した.

また午後 4 時以降ではその様相はさらに一変する.すなわち，上皮表面の微絨毛の一部は細胞質突起 cytoplasmic protrusion によつて置換され，またさきの胞体上部にみられた小胞の減少はつよまり，他方ゴ ルジ体や粗面小胞体の縮少傾向は増強した。 またライソゾーム系顆粒は増大し, その内部構造が複雑化して いくのが観察された.

胞体の基底部においては, 脂質顆粒やミトコンドリアの増加傾向がみられ, 基底膜は前日に比し, 平端化し ていた.

間質 : 浮腫は前日同様顕著であつて, 間質細胞の核は円形化し，細胞質はさらに増大し，同時にそのりボ 
ゾームの著しい増数, ミトコンドリアの増加, 粗面小胞体の内腔拡大像がみられ，その腔内電子密度の増加 が認められた。

また肥大した細胞はその細長く伸びた細胞突起によつてたがいに近接していた。

腺上皮細胞：胞体の大きさはわずかに增し，核/細胞質比もやや減少していた。ミトコンドリア，ゴルシ 体や粗面小胞体などの細胞質内小器官にみられる所見は前日に比し，著変はなかつたが，ライソン゙ーム系顆 粒は増加の傾向を示し，その中にはミトコンドリアなどを喰食した自家食胞もみられた。

腺腔内の電子密度はこの時期で最高となり, 腺腔内の小顆粒も著明に増加していたが, 微縅毛の膯大像は もはやみられなかつた。

(4) $\mathrm{L}_{5}$ 日内膜 (Photo 13,14,15,16,17, 18, 19, 20, 21，22)

late implantation stage あるいは, nidus formation とよばれるこの時期においては, flush out 法によ る泼の回收率は著しく低下し, 胚の多くは反間膜側内膜と軽く癒着している.

この時期の上皮系におけるATPase 活性は完全に消失するのに対し，ACPase 活性の増強がみられ，表 面上皮直下反間膜間質細胞では ALP-ase，ATPase，ACPase 活性の劇的な増強がみられ，しかも ALPase, ATPase 活性は細胞膜の局在していた。しかし同部における血管系の活性は著明に低下する。

\section{(A) 反間膜側における微細構造所見}

まず肧の着床する反間膜側内膜について観察してみた.

表面上皮：子宮内腔はたがいに対向する内膜の接近によつて殆んぞ消失しており，上皮は菲薄化し，その 表面は完全に細胞質突起によつておき換えられており，てのことから上皮の ALPase 活性は主として微絨 毛に局在しているてとが示唆された。 またその直下に存在する小胞は前日よりさらに減少していた。

Fig. 13. Luminal epithelium on Day $\mathrm{L}_{5}$ $\times 15,000$

Apposing luminal epithelium became close and the cytoplasmic protrusion now covered all over the epithelial surface.

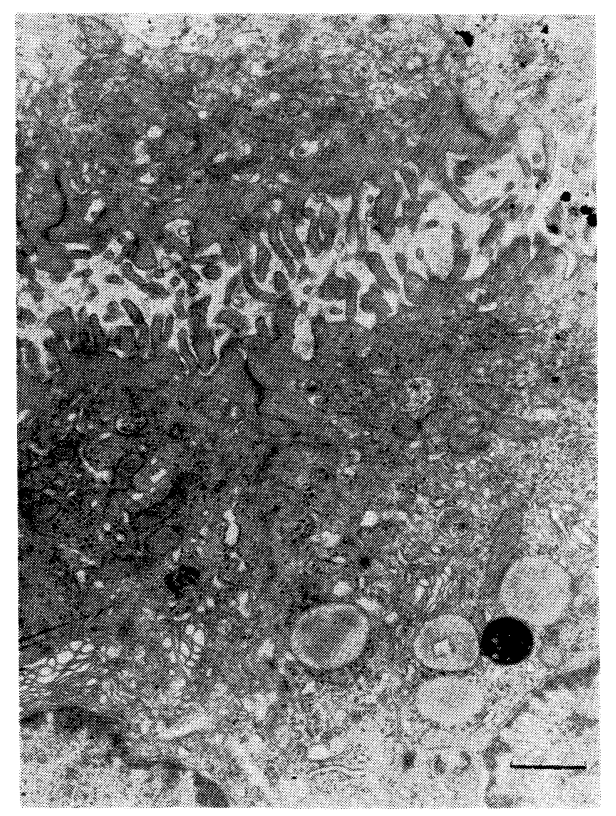

Fig. 14. Luminal epithelium on Day $\mathrm{L}_{\text {ริ }}$ $\times 20,000$

Lysosome (arrow) has increased in its number and electron density.

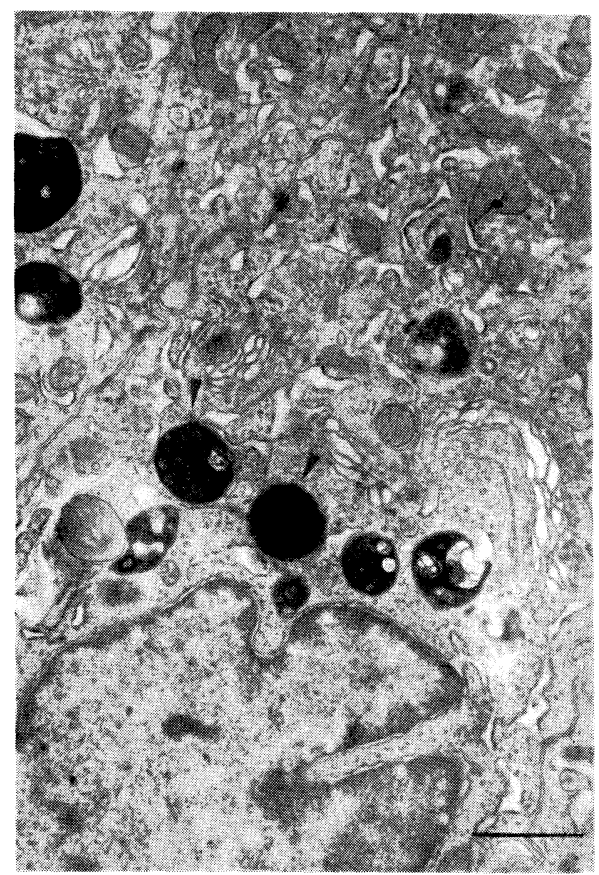


Fig. 15. Basal region of luminal epithelium on Day $\mathrm{L}_{5} \times 15,000$

Basement lamina (arrow) was straight.

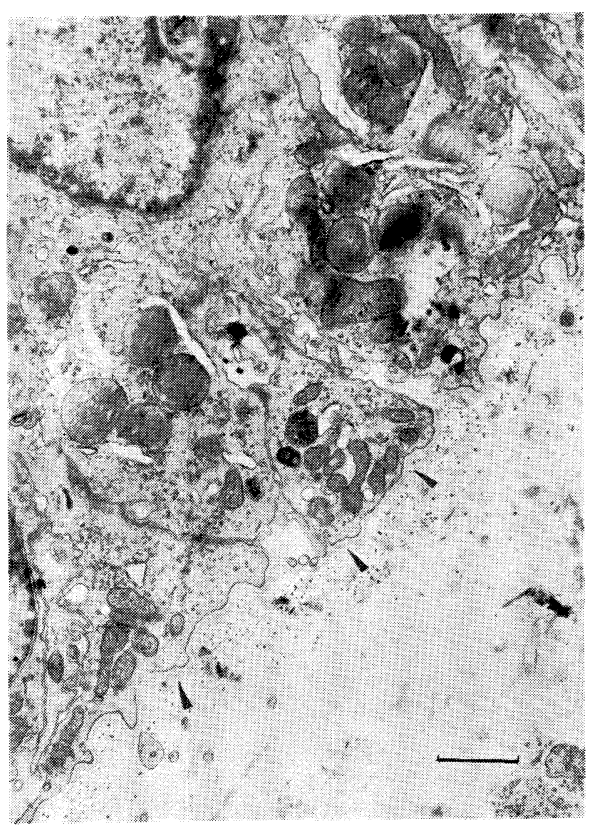

Fig. 16. Stromal cell on Day $\mathrm{L}_{5} \times 15,000$ Gellular connection with desmosome (arrow) was noted and the adjacent lymphocyte (arrow) was also observed.

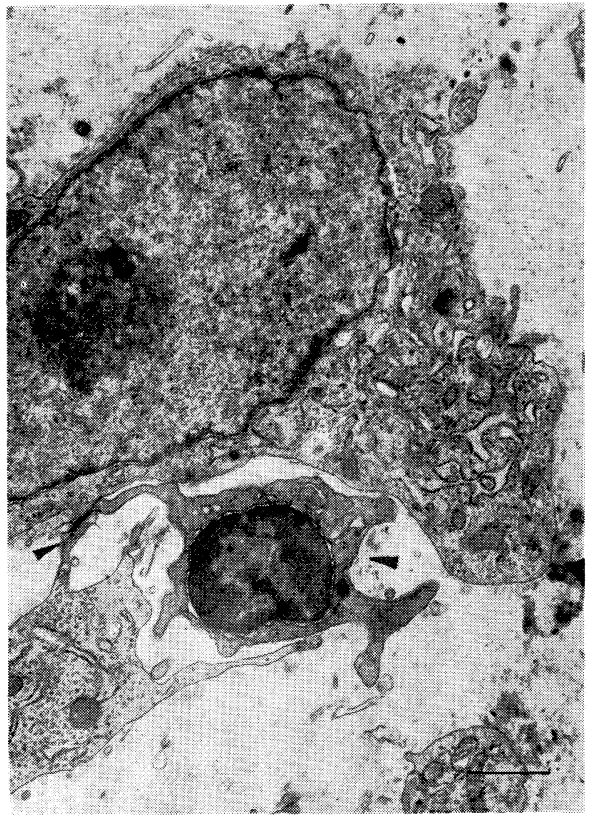

Fig. 17. Stromal cell on Day $\mathrm{L}_{5} \times 24,000$

Marked dilatation of the granular endoplasmic reticulum and the abundant ribosomes were observed. The fibrillar material (arrow) and lipid droplets were also noted.

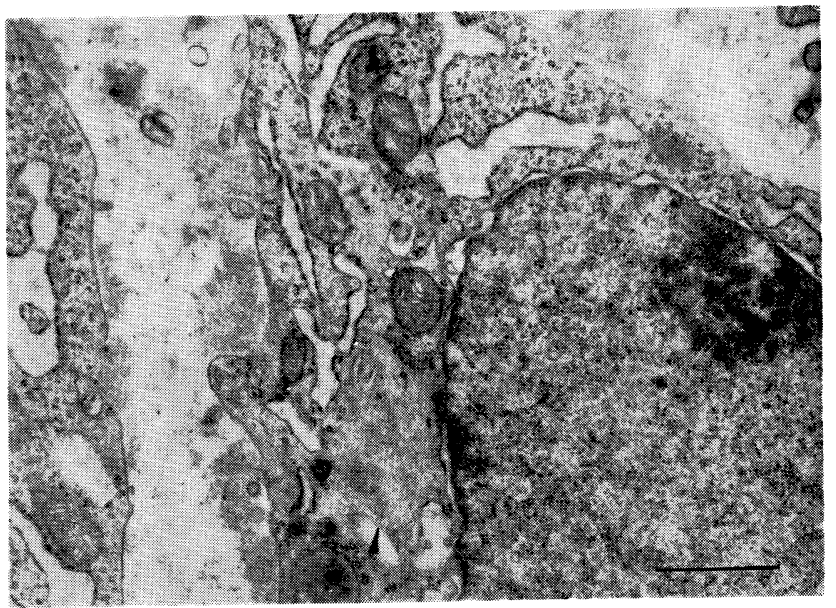


Fig. 18. Stromal cell and glandular epithelium on Day $\mathrm{L}_{5} \times 15,000$

One cilium (arrow) was observed just below the glandular epithelium situated above.

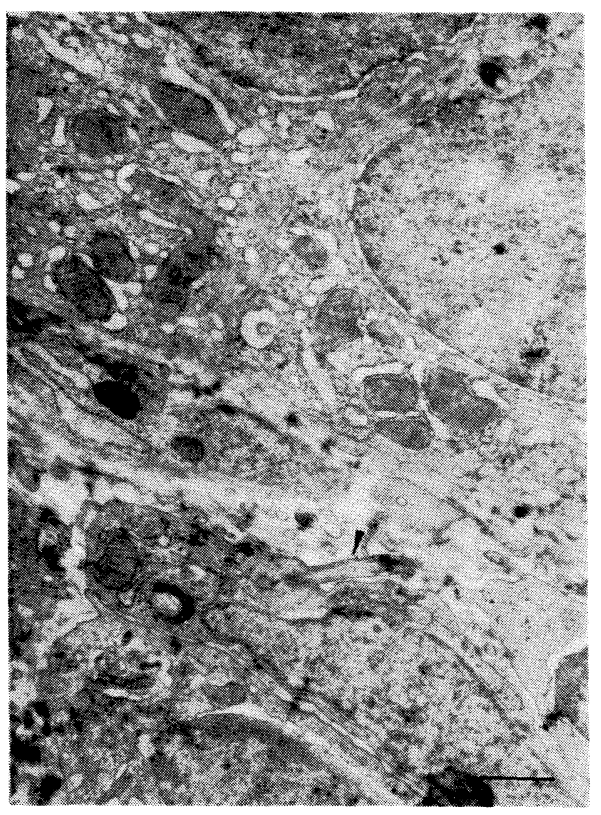

Fig. 19. Subepithelial stromal cell on Day $\mathrm{L}_{5} \times 15,000$

Many lysosomes (arrow) were observed in the stromal cell and the cytoplasmic protrusion of the stromal cell was so closed to the basal region of the luminal epithelium.

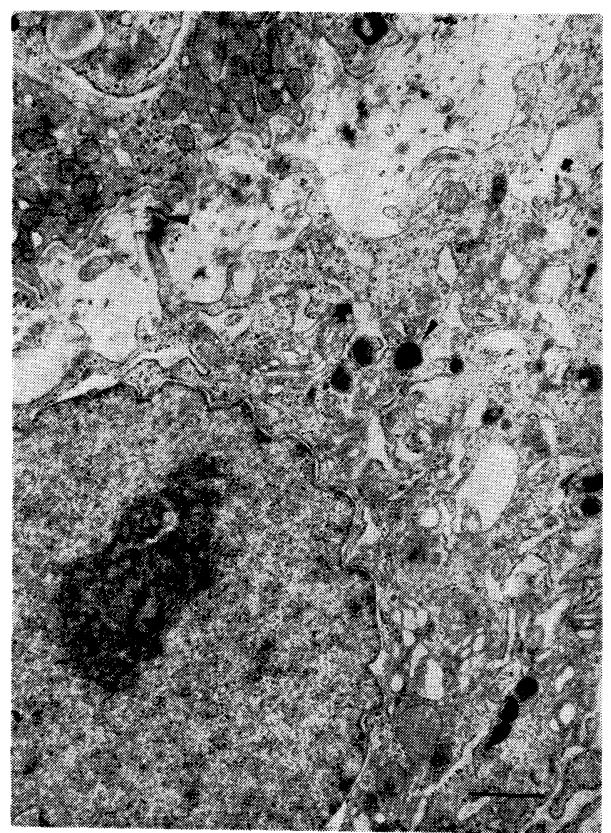

Fig. 20. Glandular epithelium on Day $\mathrm{L}_{5} \times 15,000$

The matrix of mitochondria. showed low electron density (arrow) and many vacuoles were observed.

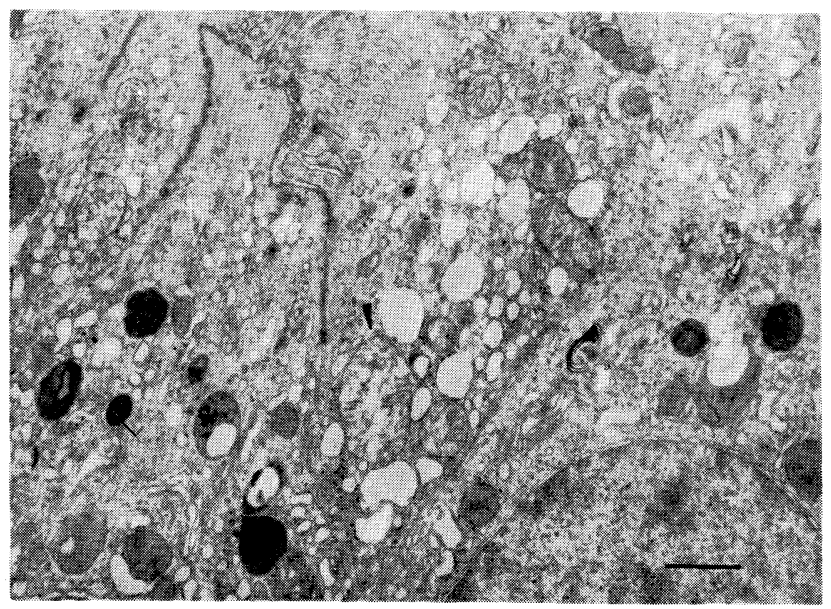


Fig. 21. Luminal epithelium on Day $\mathrm{L}_{5}$ $\times 24,000$ (mesometrial site) The cytoplasmic protrusion was also observed in this site.

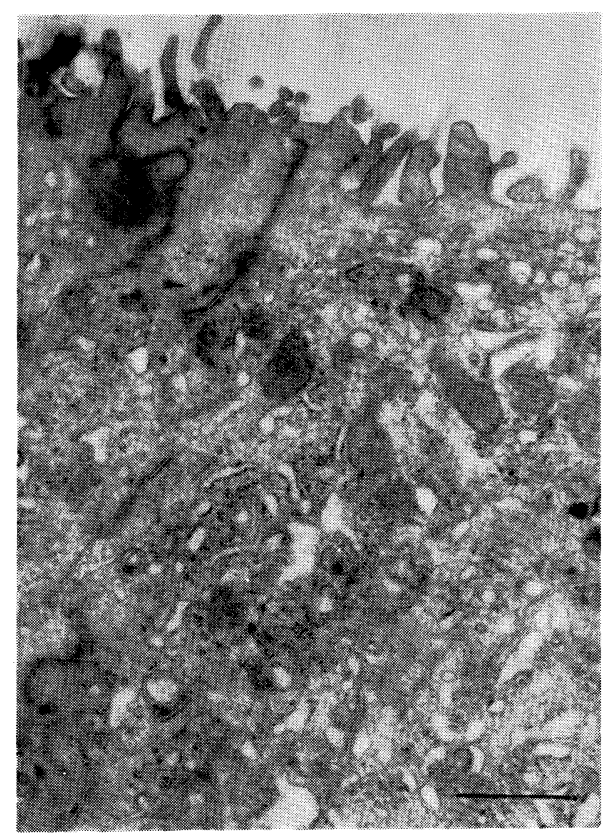

胞体上部におけるミトコンドリアは，むしろ増加 傾向を示し，核上部における脂質顆粒の増加，さき の ACPase 所見と符合するライソゾーム系顆粒の 増加やその高密度化がみられた。

他方，基底部では脂質顆粒の減少傾向がみとめら れ，さらに特徽的な所見として基底膜の平端化がみ られたが，基底膜はなお完全に保持されていた。

間質 : 細胞質の一層の肥大に加えて，種々の細胞 質内小器官の変化をみることができた。まず基底膜 直下にある間質細胞では細長く伸びた細胞質突起が 基底膜に極度に接近しており，またその部の基底膜 上部においては，乏トコンドリアが密集していた。

間質細胞質内では，リボゾームやミトコンドリア の増加に加えて, 粗面小胞体の内腔拡大像がさらに 強まり，また脂質顆粒やライソゾーム系顆粒は増数 していた.

このほか, 細胞質内に币 $100 \AA ̊ 2150 \AA$ の小線維 状物質，いわゆる fibrillar material が出現し，ま た細胞相互間にはデスモゾームによる密着，すなわ ち間質細胞の上皮化現象と見做して良い所見が得ら れた。 また同時にてれに近接してリンパ球の遊走も 観祭された。

Fig. 22. Stromal cell on Day $\mathrm{L}_{5} \times 11,000$ (mesometrial site) The outline of nucleus was round as that in the antimesometrial site, but the cytoplasma was not so enlarged.

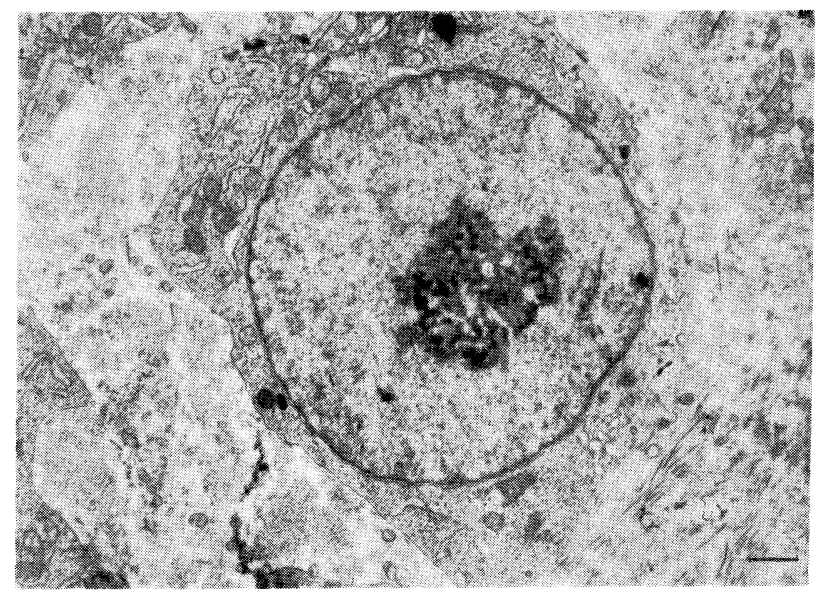

以上の様な変化のほかに，腺細胞基底膜附近の脱落膜細胞においては細胞膜間小腔が散在し，そこに繊毛 をみることができた。

腺上皮細胞：腺腔内の電子密度は前日より明らかに低下していたが，胞体上部の小胞や粗面小胞体に関し 
ては，前日とあまり大差が認められなかつた。

しかしながらミトコンドリアは減少傾向にあり，その中には，明らかに膨化傾向を示し，さらに基質内の 電子密度の低下しているものも認められた。

ラィソゾーム系顆粒は前日と同様に豊富で，胞体の基底部にいたるまで大小種々の空腔が多数分布してお り，ことに基底部では脂質顆粒の増加がみられた。

(B) 間膜側における微細構造所見

反間膜側表面上皮にみられた前述の諸変化が胚の機械的刺激に由来するものであるおどうかを検討する一 つの手段として，同一動物の間膜側内膜についても観察を行つた.

表面上皮: 表面の細胞質突起は，反間膜側と同様に出現していたが，その密生度はやや弱いうに思われ た.しかし細胞内小器官の変化に大差は認められず，またてのさい注目すべき所見として基底膜の平端化も 反間膜側と同様に出現していた．しかし，本所見は光学顕微鏡学的検索手段では明らかでない．

間質 : 間質性浮腫や，間質細胞の核の円形化がみとめられたが，細胞質の肥大は著しくなく，また粗面小 胞体の拡大像も顕著でなかつた。しかし細胞膜間のデスモゾームによる連結現象はすでに惹起されており， ライソゾーム系顆粒の増数も観察できた。

\section{III 考 察}

組織化学的検索成績からは，まず着床前期では上皮系と血管系に強い ALPase, ATPase 活性がみられ， ことに血管系では $\mathrm{L}_{3}$ 日を接点として急激な活性の増強, 換言するとその壁透過程の亢進を思わす所見を得 た。 また着床期の $\mathrm{L}_{4}$ 日では，反間膜側上皮直下の聞質細胞に membrane transport marker としての ATPase 活性が出現してくる. そして $\mathrm{L}_{5}$ 日になると，脱落膜の形成と共に，同部に強い ALPase, ATP 活性が出現し，他方同時期の反間膜側上皮においては，ALPase，活性の消失と ACPase 活性の増強がみら れた。

ところで, 今回の著者らの観察結果によると, 着床周辺期にみられる表面上皮の諸変化のうち, まず最初 に出現する微細構造上の変化は， $\mathrm{L}_{3}$ 日にみられた微絨毛の短縮と，その配列の不規則化である。乙れはそ の後にみられる微絨毛の消失や，てれに代つて表面上皮をおおう細胞質突起の出現に先行する所見である。 このような表面上皮の変化は，ヒト内膜においても分泌期に認められており (Nilsson ${ }^{7)}$ 1962), また去勢 progesterone 遅延着床ラットに少量のエストラダィオールを投与すると同様な変化の惹起されることが観察 されている (Potts ${ }^{8)}$ ら 1967). この Potts らの知見は上皮表面にみられるこの種変化が, progesterone 前作 用後の estrogen 作用を引き金として惹起されるものであるととを端的に示唆するものである.

また著者らの研究においては，ほぼ同時期に゙微絨毛表面の樹枝状構造の消失がみられたが，乙れと同様な

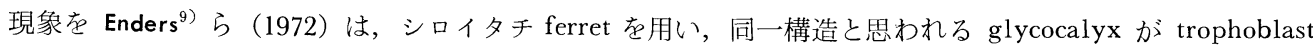
の ectoplasmic pad そ近接する部位に特異的に消失するてとを観察している。もちろんとの樹枝状構造の 保存の程度は，試料作成過程における固定の良否に大きく左右されるものではあるが，上記の Enders らの 報告や妊卵の子宮腔に下降する $\mathrm{L}_{3}$ 日内膜にはじめて出現すると言う著者らの知見を考慮すると，本所見は 内膜側における妊卵接触の徴候の一つである可能性が極めて強いものと思われる.

着床前期の $\mathrm{L}_{3}$ 日においてみられた表面上皮胞体上部の小胞の著しい増加は，同時にみられたゴルジ体の 発達，粗面小胞体の拡大，あるいは子宮胞内液の高電子密度と考元合わせ，乙の時期の表面上皮の活発な分 泌機能を推測させる所見である.

その生物学的な意義に関しては，現在のとてろあまり明らかでないが，弤卵に対する栄養源としての意義 のほかに，Mayer ら（1967）も指摘している様に，着床前期の胚は子宮腔内では機能的に dormant である にもかかわらず，乙れを他の臓器に移植すると活発化されると言う事央から，乙の時期にみられる分泌機能 の妄進を胚の着床を阻止する機構の一つとして関連づける見解もある.

さらに着床期, すなわち $\mathrm{L}_{4}$ 日において, 表面上皮に複雑化したライソゾーム系顆粒が出現し, またそれ 
らの増数や高密度化がみられたととは，乙の時期の表面上皮の機能が，前日の分泌相から吸収相へと変化す ることを示唆するものである.

このような推定を支持する事実として, 我々は同時期に行つた表面上皮の Trypanblau の取り込み結果 から， $\mathrm{L}_{4}$ 日表面上皮は $\mathrm{L}_{3}$ 日と比較して著しい色素吸収能の㫕進するてとを認めており,ての athrocytosis 能の亢進はライソゾーム系列の phagosome 機能と正の相関にあるてとが知られている (Photo 23, 24).

Fig. 23. Absorption of Trypanblau in the luminal epithelium on Day $\mathrm{L}_{3}$.

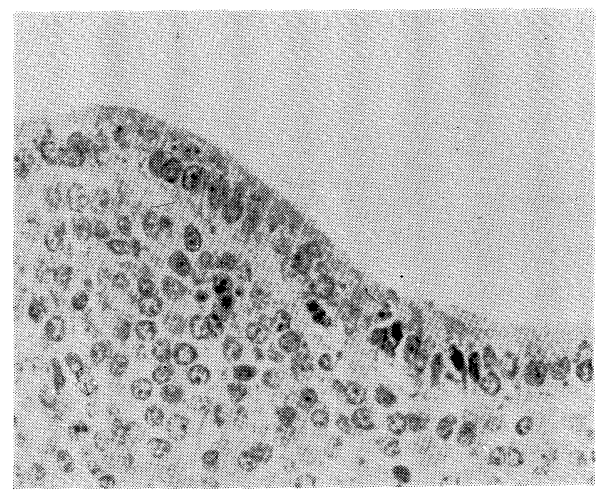

Fig. 24. Absorption of Trypanblau in the luminal epithelium on Day $\mathrm{L}_{4}$. It showed stronger athrocytosis compare to that on previous day.

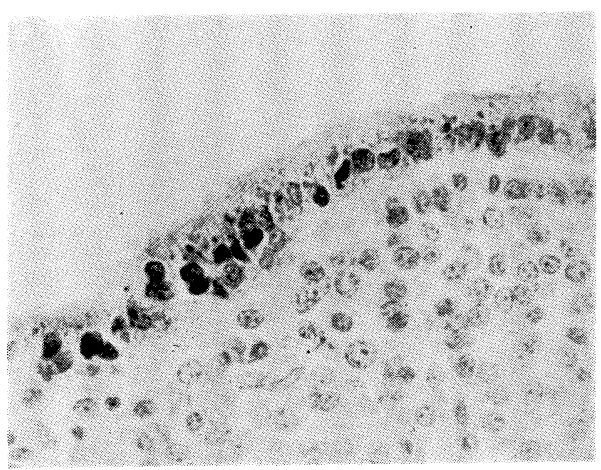

また同時期にみられる脂質顆粒の增加やその核上部への移動現象の持つ意義については, 不明であるとい わざるを得ないが，吸収された物質の貯蔵現象と関連性のある可能性も除外できない。

いずれにせよ，乙のような表面上皮の微䋘毛の短縮, 消失, 分泌相から吸収相への転換を思わせる細胞内小 器官の変化を，後述の表面上皮にみられる上皮の接近現象と一括し Nilsson (1970) は attachment reaction と呼んでおり，乙うした上皮の接近現象は先に述べた表面上皮の吸収相への転換，いいかえると，予想され る子宮内液の性状の変化，あるいはその粘調化とあいまつて，胚の内膜固定飞役立つものと推定される.

ところで, attachment reaction は Nilsson の系統的な研究によれば, マウス, ラット，ハムスターなど の偏心性着床，あるいはモルモットなどの間質着床型式をとる動物ではみられるが，ウサギ，ミンクなどの 中心性着床型式をとる種属においては出現しないといわれる。 また attachment reaction ねおこす動物は, 総して着床前にみられる胚の膨化度，さらに絨毛の内膜浸潤性が弱いことも興味深い。

つぎに $\mathrm{L}_{5}$ 日内膜表面上皮においては，上皮の菲薄化と，基底膜が間膜側の着床部位におろて平端化す ることを観察できたが，乙のような基底膜の平端化は着床部位のみならず，間膜側子宮膜基底膜でも認めら れるので, この機作に関しては, 単なる受精卵の圧迫によつて惹起される現象でなく, むしろ内膜の attachment reaction の範疇にぞくする active な反応と考えたい.

次に間質における最も早期の着床準備状態は浮腫の出現であるが，間質性浮腫 は受精卵が 卵管内にある $\mathrm{L}_{2}$ 日の時期からすでに電顕的に浮腫傾向がみられた。このような間質性浮腫はさらにその後增強し， $\mathrm{L}_{4}$ 日 で頂点に達し， $\mathrm{L}_{5}$ 日以降は弱まるが，肧着床にとつて極めて合目的な現象であると思われる.

またL $\mathrm{L}_{5}$ 日に，上皮直下の間質細胞にデスモゾームによる密着，即ちその上皮化が認められたことは前述の 通りである。

ての上皮化に関しては，すでに Enders（1967）の詳細な報告がみられるが，この生物学的意義に関して は， trophoblast による基底膜破壊後の受精卵に対する第二の barrier を形成することにあるものと思われ 
る.

こうした第一次脱落膜細胞の微細構造にみられるその他の諸変化を列記すれば，核周团の平滑化，細胞質 の肥大とそれに伴う粗面小胞体の拡大とその内腔の高電子密度化，リボゾームの増加などの諸変化であり， 周囲の非脱落膜化細胞と明瞭に区別できるようになるが，ての中でも最も劇的な変化はポリゾームの增加で あり，しばしばU字状，あるいはコイル状を呈する。

これらに加え細胞間に小隙を生じ，そこには細長い細胞突起が認められ，上皮性細胞ととに分泌機能を有 する細胞と組織構築上の類似性がみられたととは，上記した barrier としての意義のほかに，本細胞にお ける旺盛な分泌，あるいは吸収機能を示唆しており，てのような考方方を裏付けする所見として，前述の脱 落膜細胞に極めて強い ATPase, alkaline phosphatase, acid phosphatase 活性の局在するという所見老指 摘できる.

このほか fibrillar material も明膫に認めるようになるが, この種 fibrillar material の出現は, Jollie ${ }^{10}$ ら（1965）は実験的脱落膜嗹形成時に，また Enders ら（1967）はやはりラットの正常妊娠脱落膜細胞にて れを認めており，そのほか線維芽細胞，血管上皮細胞，あるいは hepatoma においてもみられると言われ るが，その生物学的意義は不明である。

最後に，腺上皮細胞の動きについては，肧発育に対して limiting factor 的な役割を演ずる uteroglobinblastokinin の形成機構などの問題とも関連して興味ある課題であるが，その分泌動態に関する業績はこれ まで少い"11).

ての点についての著者らの見解を述べると, 前述した様に $\mathrm{L}_{2}$ 日においては微絨毛の膨大像, $\mathrm{L}_{3}$ 日や $\mathrm{L}_{4}$ 日では小顆粒の腺腔内への蓄積などの所見が観察されたが，現時点での研究結果からその分泌様式を明確に 結論することは早計である。しかし一応黑住の分䟤型式の分類（1965）に準ずると，微䋐毛の膨大を認めた ことから第而型 (microapocrine mechanism) あるいは腺腔内に多くの小顆粒を認め得たととから，第 $\mathrm{V}$ 型 (diacrine mechanism) 飞類するものであろうと予想される.

また腺腔内の電子密度は着床期の $\mathrm{L}_{4}$ 日にわいて頂点に達したが，乙れは著者らの別途実験における組織 化学的観察において, diastase resistant PAS 陽性物質が同じくこの時期に最高となる成績とほぼ一致して いる.

さらに腺上皮細胞内小器官の変化に関しては, protein 産生小器官のポリゾーム, 粗面小胞体, また粗面 小胞体でつくられた分泌性 蛋白の糖質添加の場であるゴルジ体の動態が興味深い.すなわち uteroglobinblastokinin の本態は分子量27000前後の小分子 glycoprotein であるととが Daniel ら (1971) によつて確認 されているからである. そしててれらの腺上皮細胞の小器官は $\mathrm{L}_{2}$ 日から $\mathrm{L}_{4}$ 日にかけて増加，もしくは増 大すると言う事実をたしかめることができた。

しかし $\mathrm{L}_{5}$ 日では, すでそミトコンドリア基質の電子密度の低下, 空胞の出現などの機能低下所見を涩め ており，著者らは光顕的にもとの時期に $\mathrm{H}^{3}$-uridine, $\mathrm{H}^{3}$-methionine のとりこみや ${ }^{12)} \mathrm{SDH}$ 活性の急激な 低下 ${ }^{23)}$ を別の実験で観察している.

\section{ま と め}

胚着床の機構を知る目的で, 着床周辺期ラット子宮内膜についてその微細構造の変化を観察し, 同時期に みられる組織化学的所見と共に，その意義について考察した。

(1) $\mathrm{L}_{2}$ 日では ALPase 活性は主として，上皮系や血管壁に局在し，一方表面上皮には規則正しく配列す る微絨毛と, その表面をおおう樹枝状構造がみられた。 このほか間質の浮腫傾向, 腺上皮細胞の微絨毛の膨 大像が観察された。

（2） $\mathrm{L}_{3}$ 日では上皮系の ATPase 活性の増加，間質血管系の ALPase, ATPase 活性の増強がみられた。 表面上皮の微絨毛の短縮傾向と共に樹枝状構造は消失し, 胞体上部の小胞の著しい増加，ゴルジ体の発達や 粗面小胞体の拡大像がみられた。 基底膜は著しく屈曲し, また間質の浮腪傾向の増強, 胞体の肥大, 小器官 
の発達がみられた。腺上皮細胞ではゴルジ体の発達と共に腺腔内に小顆粒を認めた.

（3） $\mathrm{L}_{4}$ 日においては，強い反間膜側内膜血管系 ALPase, ATPase 活性のほか飞上皮直下間質細胞に ACPase 活性の増加とATPase 活性の出現をみた. 微細構造では, 表面上皮の微絾毛や小胞の減少傾向, 脂質顆粒の核上部移動，ライソゾーム系顆粒の増加をみ，また間質細胞の胞体の増大，リボゾームの増加， 粗面小胞体の内腔拡大像やその腔内電子密度の増加をみた。また腺腔内の電子密度は最高となり，同時に腺 腔内の小顆粒も著明に増加していた。

（4） $\mathrm{L}_{5}$ 日においては，反間膜側間質細胞の諸酸素活性の一層の増強がみられ，ALPase, ATPase 活性は 細胞膜に局在していた。 また反間膜側表面上皮は細胞質突起でわおわれ，核上部脂質顆粒の増加，ライソゾ 一ム系顆粒の高密度化と共に, 基底膜の平端化をみた。間質の浮腫傾向は減少し, 間質細胞は上皮化し, fibrillar material や紻毛の出現がみられた，腺上皮細胞内ではミトコンドリアの膨化や空胞形成をみ，ま た腺腔内の電子密度は低下していた.

他方，間膜側表面上皮にも，細胞質突起の結合や基底膜の平端化がみられ，また間質の浮腫傾向，間質細 胞核の円形化をみたが，細胞の肥大度は反間膜側の間質細胞ほど著しくなかつた。

稿を終るにあたり, 御指導, 御校閲を晹わつた東條伸平教授, また, 始終御指尊いただきました本学第二 解剖学教室, 溝口史郎教授に衰心より深謝いたします。

\section{文献}

1) Enders, A.C. and S.J. Schlafke : Am. J. Anat. $120: 185$ (1967)

2) Mayer, G., O. Nilsson and S. Reinius : Z. Anat. $126: 43$ (1967)

3) Nilsson,O. : Ovo-Implantation. Human Gonadotropins and Prolactin 1970, 52 S. Karger Basel Munchen New York 4 4) Tachi, S., C. Tachi and H.R. Linder : J. Reprod. Fert. $21: 37$ (1970) 5 5) 飯塚理八：第23回日本産科婦人科学会総会 宿題報告要旨, (1971). 6 6) 林 要, 武木田博祐, 松岡謙二: 第22回日本産科婦人科学会総会講 演集，(1970). 7) Nilsson, O.: Z. Zellforsch. mikrosk. Anat. $56: 803$ (1962) 8) Potts, D.M., and A. Psychoyos : C.r. hebd. Séanc. Acad. Sci. Paris $264: 370$ (1967a) 9 9) Enders, A.C., and S.J. Schlafke : Am. J. Anat. $133: 291$ (1972) $\quad$ 10) Jollie, W.P., and S.A. Bencosme : Am. $\begin{array}{lll}\text { J. Anat } 116: 217 \text { (1965) } & \text { 11) Daniel, J.C. : Advances in the Biosciences 1971, } 191 \text { Pergamon }\end{array}$ Press Vieweg 12) Takekida, H. : Acta. Obst. et Gyneac. Jap. $18: 200(1971) \quad$ 13) 林 要, 高野申吾, 武木田博祐: 産婦進歩, $20: 375$, (1968). 